\title{
Identifying sources of coal spontaneous heating in mine workings using aerogas control automatic systems
}

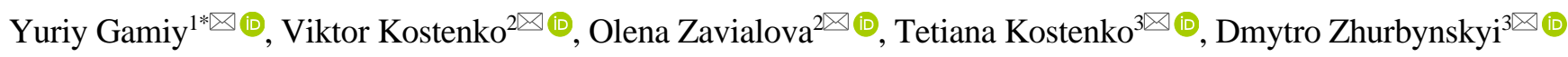 \\ ${ }^{1}$ The Public Militarized Mine-Rescue Service, Myrnohrad, 85323, Ukraine \\ ${ }^{2}$ Donetsk National Technical University, Pokrovsk, 85300, Ukraine \\ ${ }^{3}$ Cherkasy Institute of Fire Safety named after Chornobyl Heroes of National University of Civil Defense of Ukraine, Cherkasy, 18034, Ukraine \\ *Corresponding author: e-mail gamiyyv@gmail.com, tel.+380500469222
}

\begin{abstract}
Purpose. Substantiation of the possibility for expanding the modern Aerogas Control (AGC) systems functions when using them to identify the processes of spontaneous heating, spontaneous ignition of coal and gas contamination at the mining site of the coal mine.

Methods. This paper presents the dynamics study of selecting 15 air distribution gas samples from the specified places, using the MATLAB system and Simulink extension packages. Gas samples have been selected in the 14th southern longwall face of block No.10 at Mining Administration "Pokrovske" during March 23-27, 2019, where an emergency situation related to gas contamination occurred on March 15, 2019.

Findings. The experimental data has been processed on the carbon monoxide emission in mine workings of the extraction area, longwall face, technological pipelines, and on air distribution. A carbon monoxide increase in mine workings has been determined from $0.0000-0.0002 \%$ in the air jet, incoming the site, to $0.0001-0.0003 \%$ in the jet, outcoming from the site. Moreover, maximal invasion of carbon monoxide to the stope mine working occurred during operations of breaking and transporting coal within the extraction area, and when these activities were stopped and there was no fresh beaten material, the invasion of carbon monoxide was reduced to the background content level. It has been proved that improvement of the existing AGC systems by adding the sensors for measuring tracer gases and airflow rate, as well as the "artificial intelligence" to information processing units, will make possible to determine absolute and relative readings for sources identification of spontaneous coal heating at early stages.
\end{abstract}

Originality. For the seam $d_{4}$ conditions, the nature and peculiarities have been revealed of the carbon monoxide emission and the effects of ventilation during extraction operations at the mining site, while previous known studies were devoted to the carbon monoxide emission from the seams $k_{5}, l_{1}, m_{4}{ }^{2}$ with a change in the granulometric composition.

Practical implications. Constant monitoring of aerological threats will make it possible to take appropriate measures for limiting the ventilation and gas hazards effects, the danger of endogenous fires.

Keywords: AGC systems, spontaneous heating and spontaneous ignition of coal, extraction area, endogenous fire

\section{Introduction}

Endogenous fires in coal mines are one of the dangerous and complex types of underground accidents in the world mining industry. They arise slowly in hard-to-reach places, such as mined-out space, geological disturbance zones of seams, virgin areas, broken rock mass refuse, etc., and, when reaching a critical temperature, a rapid ignition of a combustible medium occurs [1]-[4].

In Ukraine, the situation has worsened significantly with the war beginning. The main laboratory facilities for predicting, operational control and preventing the sources formation of spontaneous heating and spontaneous ignition of coal at the mining site, together with coal institutes (DP DonVUHI, MakNDI, NDIHD), have remained in the territory uncon- trolled by the state. Despite the efforts of manufacturers and mine-rescuers, fires from spontaneous coal ignition [5], [6] occur, and they are accompanied by significant labor costs to eliminate them, demurrages of longwall faces and economic losses (Table 1).

The problem of performing the operational control over the fire situation state in the mine extraction areas is still relevant. One of the fire monitoring methods, according to the authors, is the use of continuous Automatic Gas Control (AGC) means in mine workings.

Industrial security and labor safety of miners are in unsatisfactory condition. Detecting fires, gas contamination of mine workings and extraction areas at the early stages will give an ability to eliminate accidents in the early stages, as well as to ensure the miners' safety [7]. 
Table 1. General indicators of the endogenous accidents rate in the Donbass mines controlled by Ukraine from 2014 to 2017

\begin{tabular}{ccccc}
\hline Year & $\begin{array}{c}\text { The } \\
\text { number } \\
\text { of fires }\end{array}$ & $\begin{array}{c}\text { Duration of fire } \\
\text { extinguishing, } \\
\text { hours }\end{array}$ & $\begin{array}{c}\text { Labor } \\
\text { intensity, } \\
\text { man-hour }\end{array}$ & $\begin{array}{c}\text { Economic } \\
\text { damage, mln. } \\
\text { UAH }\end{array}$ \\
\hline 2014 & 2 & 458.4 & 4829.0 & 2.200 \\
2016 & 2 & 639.2 & 14199.6 & 5.931 \\
2017 & 1 & 119.3 & 1620.3 & 0.479 \\
2018 & - & - & - & - \\
2019 & 1 & 129.0 & 3934.0 & 1.634 \\
Total & 6 & 129 & 24582.9 & 10.244 \\
\hline
\end{tabular}

One of the results of the spontaneous ignition process is an increase in the fraction of carbon monoxide and hydrogen in the air, which is released from the source due to oxidation and thermal degradation of coal. This process occurs continuously, while the volume of gas release is constantly growing. Therefore, in order to identify early signs of coal spontaneous heating, it is necessary for each extraction area to determine the background content of carbon monoxide and hydrogen [8]. To identify the spontaneous heating and spontaneous ignition sources, the level of gases background content should be continuously compared with current indicators as the basis for identifying negative processes [9].

The tracer gases (hydrogen and carbon monoxide) release into ventilation air jets is caused not only by spontaneous heating, but also as a result of the coal massif destruction by rock pressure (the formation of technogenic fractures) and the coal seam collapse by mining machines (combines, plows, drilling rigs, chipping hammers, etc.). Therefore, the task of distinguishing the tracer gases release as a result of thermal or mechanical coal destruction is an urgent task [10], [11].

It should be noted that the gas-dynamic incompatibility of measurements at different points to a certain extent may be formed because of the gas wave propagation during its movement over mine workings, the difficulty of determining the true value of the average air velocity at the site between the measuring points, as well as the other factors' influence [12]-[16].

Predicting and identification of emergencies is largely facilitated by the use of means for continuous automatic control of situation in mine workings [17]. Today, automated systems UTAS, KAGI, APSS, AKRD and others are used at coal mining enterprises. The UTAS system measures the carbon monoxide content and air velocity in the mine working by means of various sensors, which are usually located in different ventilation system parts.

Modern methods of thermodynamic processes control in mine workings of the extraction area provide for the simultaneous measurement of the dynamics of changes in the tracer gases concentration, that is, as relative indicators, so absolute ones - volumes of ingress per unit time [18]-[23]. Existing Ukrainian automatic gas control systems are not designed for this purpose.

The closest to solving this problem are the systems for controlling the ventilation jet velocity, measuring the gases concentration at the mining site, of the Polish company EMAG [22], [24]-[27]. he methane emission calculations based on the sensor readings current values are implemented in them. Figure 1, as an example, shows a window of a certain program part, which is responsible for determining methane emissions in the extraction area, which can be calculated online or at the request of the operator.

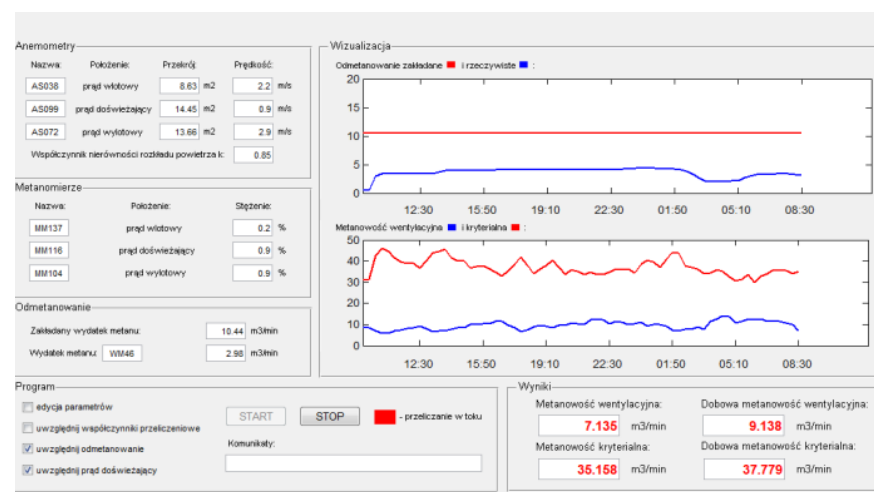

Figure 1. The window with the methane emission balance in the extraction area [22]

The left part of the window comprises the current sensors readings of air jet velocity, methane concentration, relative to the permissible level of methane and other indicators, based on which further calculations are made. The right side presents daily graphs of the predicted calculated and real methane content (upper diagram), as well as indicators of methane emission into the air jet, both real and permissible. In the lower right window part, the program presents the current and daily values of methane emission and its permissible limits.

Performing such control, in addition to a good knowledge of the ventilation system current state, requires the ability to predict the level of gas release in the long-term [28] and short-term prospects [29], [30].

\section{Research methodology}

The CO gas release has been analysed using the example of an extraction area of the $14^{\text {th }}$ southern longwall face of block No. 10 at Mining Administration "Pokrovske" PJSC, where a "gas contamination" emergency occurred on March 15,2019 . In block No. 10 , the $14^{\text {th }}$ southern longwall face is located in the south-eastern part of the mine field. The design length of the extraction panel is $1732 \mathrm{~m}$ with the longwall face length of $290 \mathrm{~m}$. Coal seam $d_{4}$ over an area of the extraction field has a simple structure. Geological thickness varies within $1.25-1.75 \mathrm{~m}$, the average thickness along the panel $-1.47 \mathrm{~m}$.

Longwall face is ventilated according to the scheme of the reverse jet $1-\mathrm{M}-\mathrm{N}-\mathrm{v}-\mathrm{pt}$ ventilation type, where $1-$ is the type of sequential separate methane and other harmful gases dilution according to the sources of emission; $\mathrm{M}$ - subtype, direction of the outcoming jet release from the longwall face to the coal massif; $\mathrm{N}$ - class, independent ventilation (single longwall face); v - subclass, outcoming air movement along the longwall face; $\mathrm{pt}$ - type, straight-jet direction of fresh and outcoming air [31]. According to the calculation, for airing the $14^{\text {th }}$ southern longwall face $1666 \mathrm{~m}^{3} / \mathrm{min}$ is necessary (Fig. 2). Permissible load according to the gas factor is $4852 \mathrm{t} /$ day. As a means of preventing gas release, an isolated methane drainage (pipeline diameter of $1000 \mathrm{~mm}$ ), degassing of adjacent seams using wells drilled ahead of the stope face through the ventilation drift of the $14^{\text {th }}$ southern longwall face $\left(13^{\text {th }}\right.$ southern belt entry) to the surface vacuum-pump station (VPS) (pipeline diameter of $426 \mathrm{~mm}$ ), degassing of the mined-out space with the help of a "candle" to the surface VPS (pipeline diameter $325 \mathrm{~mm}$ ) are used. The points layout of gas sampling (numbering in triangles) in the extraction area is shown in Figure 2. 


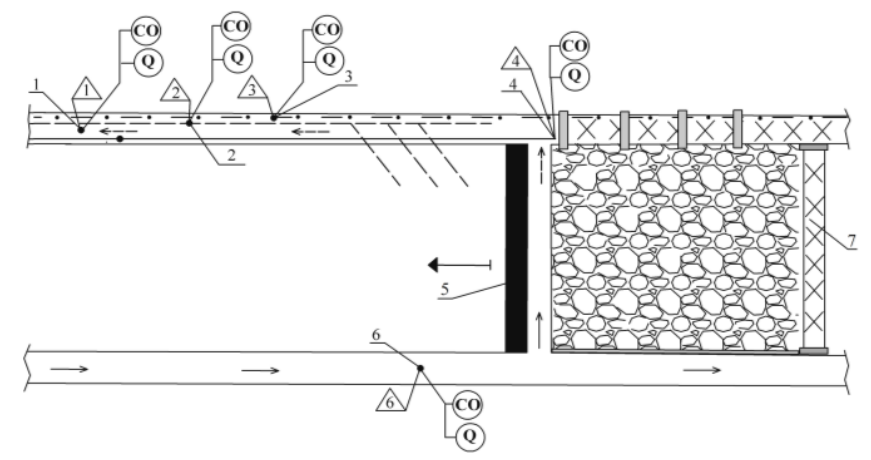

Figure 2. Scheme of mine workings network and places (triangles) for selecting gas-air samples in the extraction area of the $14^{\text {th }}$ southern longwall face of block No. 10 at Mining Administration "Pokrovske": 1-upper entry; 2, 3 - degassing columns $0426 \mathrm{~mm}$ and $0325 \mathrm{~mm}$; 4 - pipeline of the isolated methane drainage by fan VMTSG-7M; 5 - belt entry; 6 - longwall face; 7 - ventilation crosscut

In mine workings of the $14^{\text {th }}$ southern longwall face, the volumetric fraction of carbon monoxide and hydrogen content was tested, according to the results of which the following gas concentrations $\mathrm{CO}-0.0003 \%, \mathrm{H}_{2}-0.0004 \%$ have been accepted as background values of the volumetric fractions of carbon monoxide and hydrogen in mine workings (Table 2).

Table 2. The content of $\mathrm{CO}$ and $\mathrm{H}_{2}$ in mine workings of the $14^{\text {th }}$ southern longwall face of block No. 10

\begin{tabular}{|c|c|c|}
\hline Gas composition control points & $\begin{array}{l}\text { Carbon } \\
\text { monoxide } \\
(\mathrm{CO}), \%\end{array}$ & $\begin{array}{c}\text { Hydrogen } \\
\left(\mathrm{H}_{2}\right), \%\end{array}$ \\
\hline $\begin{array}{l}14^{\text {th }} \text { southern belt entry of the seam } \\
d_{4} \text { - incoming jet }-20 \mathrm{~m} \text { from the } \\
\text { ventilation crosscut of the } 14^{\text {th }} \text { south- } \\
\text { ern longwall face }\end{array}$ & 0.0000 & 0.0000 \\
\hline $\begin{array}{l}13^{\text {th }} \text { southern belt entry of the seam } \\
d_{4}-\text { jet outcoming from the } 14^{\text {th }} \\
\text { southern longwall face of the seam } \\
d_{4}-20 \mathrm{~m} \text { from the longwall face } \\
\text { window }\end{array}$ & 0.0000 & 0.0000 \\
\hline $\begin{array}{l}13^{\text {th }} \text { southern belt entry of the seam } \\
d_{4}-\text { jet outcoming from the extraction } \\
\text { area }-20 \mathrm{~m} \text { to the ventilation crosscut } \\
\text { with the } 14^{\text {th }} \text { southern longwall face }\end{array}$ & 0.00010 & 0.00013 \\
\hline $\begin{array}{l}\text { pipeline of an isolated methane gas } \\
\text { drainage - in the pipeline near the } \\
\text { longwall face window }\end{array}$ & 0.00020 & 0.00020 \\
\hline $\begin{array}{l}\text { pipeline } \varnothing 426 \mathrm{~mm} \text { of adjacent seams } \\
\text { degassing }-20 \mathrm{~m} \text { to the } 13^{\text {th }} \text { southern } \\
\text { belt entry }\end{array}$ & 0.00063 & 0.00083 \\
\hline $\begin{array}{l}\text { pipeline } \varnothing 325 \mathrm{~mm} \text { of the mined-out } \\
\text { space degassing with "candles" - } \\
20 \mathrm{~m} \text { to the } 13^{\text {th }} \text { southern belt entry }\end{array}$ & 0.00026 & 0.00020 \\
\hline
\end{tabular}

The rock mass is transported from the $14^{\text {th }}$ southern longwall face using the SZK-260/852 dragconveyer, coal is transloaded from the longwall face conveyor to the PZF-260/852 beam stage loader unit, then to the 2LT100 type extensible belt conveyor, along the $14^{\text {th }}$ southern belt entry, conveyer passage of the southern panel.

At the time of arising emergency, the stope face receded from the assembling passage at $946 \mathrm{~m}$, the length of mine working with a fresh air jet (14 ${ }^{\text {th }}$ southern belt entry) was $1236 \mathrm{~m}$, and the length of mine working with an outcoming air jet was 1195 m (Fig. 3).

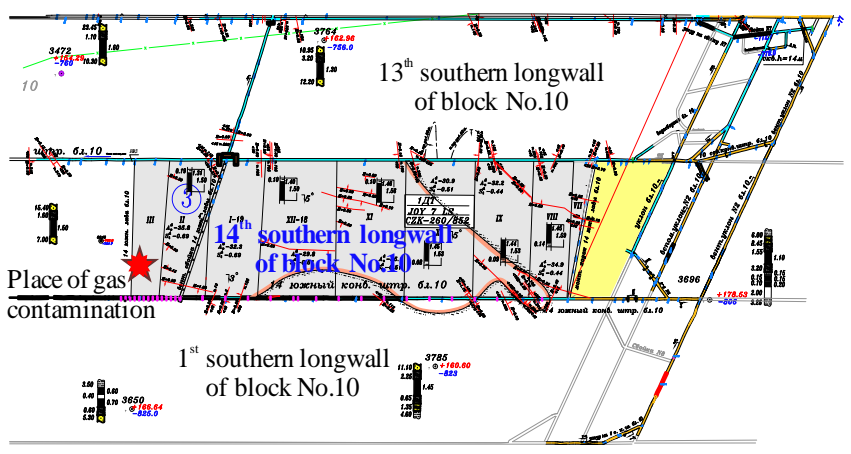

Figure 3. Mining operations plan of the $14^{\text {th }}$ southern longwall face of block No. 10 at the time of an emergency

On March 15, 2019, in the stope mine working of the $14^{\text {th }}$ southern longwall face in the area of sections No. 52-53, the carbon monoxide (CO) concentration excess was identified in the mine atmosphere. At the time of arising emergency, coal mining operations were in progress at the site and 31 workers were there. Mining operator of Mining Administration "Pokrovske" called up an operative platoon of No. 10 MineRescue Squad of the State Militarized Rescue Service in the coal industry according to the emergency situation of the "gas contamination" nature in the $14^{\text {th }}$ southern longwall face.

\section{Results and discussion}

According to the exploration results of the stope mine working of the $14^{\text {th }}$ southern longwall face, it was found that there were no smoke content and visible combustion sources in the stope mine working. The gas situation at the site, according to the express analysis, was as follows, \%:

$-14^{\text {th }}$ southern longwall face (in sections No. 50-52): $\mathrm{CH}_{4}-0.0 ; \mathrm{CO}-0.0008$;

- dead end of abandoning the $14^{\text {th }}$ southern longwall face: $\mathrm{CH}_{4}-0.4 ; \mathrm{CO}-0.0007$;

$-13^{\text {th }}$ southern belt entry: $\mathrm{CH}_{4}-0.7 ; \mathrm{CO}-0.0008$.

Because of the obvious fire signs absence and for preventive purposes, it was decided to feed a water-foam solution using "Pyrocool" cartridges to the mined-out space of the $14^{\text {th }}$ southern longwall face in the area of No. 52-53 sections using water-jet fire spears.

Since the roof rocks are represented mainly by highstrength sandstone, it was not possible to hammer fire spears into the collapsed rock massif, which resulted in the placing fire peaks along fractures between the caved blocks. Simultaneously with these measures, water-foam solution was supplied to the mined-out space of the extraction area behind the powered support sections using the "Blizzard" foam generator and the ULPP unit located in the dead end of the $13^{\text {th }}$ southern longwall face; gas and temperature measurements were taken along the entire length of the stope face. According to the gas surveys results, there were no excesses of the maximum permissible concentration (MPC) of mine gases; the temperature in the stope mine working did not exceed $26^{\circ} \mathrm{C}$.

On March 23, 2019, the mining operations were resumed in the $14^{\text {th }}$ southern longwall face. To study the nature of the carbon monoxide debit $\left(V_{\mathrm{co}}, 1 / \mathrm{min}\right)$, the results of gas samples analysis, taken from March 23, 2019 to March 27, 19 in the $14^{\text {th }}$ southern longwall face (Fig. 3.) were used at the end of each repair shift and when mining coal on working shifts. The dynamics of mine gases emission according to 15 samples from each measurement point are presented in Tables 3-7. 
Table 3. The dynamics of the gas situation in the $13^{\text {th }}$ southern belt entry

Point $1.13^{\text {th }}$ southern belt entry of block No. 10 (jet outcoming from the site)

\begin{tabular}{cccccccc}
\hline Date & \multirow{2}{*}{ Time } & $\begin{array}{c}\mathrm{CO}_{2}, \\
\%\end{array}$ & $\begin{array}{c}\mathrm{CH}_{4}, \\
\%\end{array}$ & $\begin{array}{c}\mathrm{O}_{2}, \\
\%\end{array}$ & $\mathrm{CO}, \%$ & $\begin{array}{c}Q, \\
\mathrm{~m}^{3} / \mathrm{min}\end{array}$ & $\begin{array}{c}\mathrm{T}, \\
{ }^{\circ} \mathrm{C}\end{array}$ \\
\hline 23.03 .19 & $12: 30$ & 0.1 & 0.6 & 20.3 & 0.0001 & 1398 & 24 \\
23.03 .19 & $18: 05$ & 0.1 & 0.5 & 20.3 & 0.0002 & 1398 & 26 \\
23.03 .19 & $23: 30$ & 0.1 & 0.6 & 20.3 & 0.0002 & 1398 & 26 \\
24.03 .19 & $06: 00$ & 0.1 & 0.7 & 20.3 & 0.0001 & 1398 & 25 \\
24.03 .19 & $11: 20$ & 0.2 & 0.6 & 20.3 & 0.0002 & 1480 & 25 \\
24.03 .19 & $19: 15$ & 0.1 & 0.9 & 20.2 & 0.0003 & 1480 & 26 \\
25.03 .19 & $00: 35$ & 0.2 & 0.5 & 20.3 & 0.0002 & 1480 & 23 \\
25.03 .19 & $07: 25$ & 0.1 & 0.9 & 20.2 & 0.0003 & 1480 & 24 \\
25.03 .19 & $12: 55$ & 0.1 & 0.7 & 20.3 & 0.0003 & 1465 & 23 \\
25.03 .19 & $18: 00$ & 0.1 & 0.7 & 20.3 & 0.0003 & 1465 & 25 \\
26.03 .19 & $01: 35$ & 0.1 & 0.9 & 20.1 & 0.0003 & 1465 & 25 \\
26.03 .19 & $06: 20$ & 0.2 & 0.6 & 20.3 & 0.0001 & 1465 & 27 \\
26.03 .19 & $12: 30$ & 0.2 & 0.5 & 20.3 & 0.0002 & 1479 & 25 \\
26.03 .19 & $17: 25$ & 0.1 & 0.5 & 20.4 & 0.0002 & 1479 & 28 \\
27.03 .19 & $00: 55$ & 0.1 & 0.8 & 20.2 & 0.0002 & 1479 & 29 \\
\hline
\end{tabular}

Table 4. The dynamics of the gas situation in the $13^{\text {th }}$ southern belt entry (degassing pipeline $0426 \mathrm{~mm}$ )

Point $2.13^{\text {th }}$ southern belt entry of block No. 10 (degassing pipeline $\varnothing 426 \mathrm{~mm}$ )

\begin{tabular}{ccccccc}
\hline Date & \multirow{2}{*}{ Time } & $\begin{array}{c}\mathrm{CO}_{2}, \\
\%\end{array}$ & $\begin{array}{c}\mathrm{CH}_{4}, \\
\%\end{array}$ & $\begin{array}{c}\mathrm{O}_{2}, \\
\%\end{array}$ & $\mathrm{CO}, \%$ & $\begin{array}{c}Q, \\
\mathrm{~m}^{3} / \mathrm{min}\end{array}$ \\
\hline 23.03 .19 & $12: 35$ & 0.7 & 10.9 & 17.5 & 0.0006 & 37 \\
23.03 .19 & $17: 50$ & 0.5 & 12.0 & 17.5 & 0.0008 & 37 \\
23.03 .19 & $23: 20$ & 0.4 & 16.0 & 16.9 & 0.0008 & 37 \\
23.03 .19 & $23: 20$ & 0.4 & 16.0 & 16.9 & 0.0008 & 37 \\
24.03 .19 & $06: 05$ & 0.9 & 18.0 & 16.1 & 0.0008 & 37 \\
24.03 .19 & $11: 30$ & 0.8 & 14.0 & 16.8 & 0.0009 & 37 \\
24.03 .19 & $18: 50$ & 1.0 & 22.0 & 15.2 & 0.0009 & 37 \\
25.03 .19 & $01: 15$ & 0.9 & 16.0 & 16.1 & 0.0008 & 37 \\
25.03 .19 & $07: 00$ & 0.5 & 18.0 & 15.9 & 0.0008 & 37 \\
25.03 .19 & $12: 20$ & 1.1 & 19.0 & 16.0 & 0.0007 & 37 \\
25.03 .19 & $18: 10$ & 0.7 & 18.0 & 15.1 & 0.0009 & 37 \\
26.03 .19 & $01: 40$ & 0.5 & 16.0 & 16.7 & 0.0007 & 37 \\
26.03 .19 & $06: 25$ & 0.9 & 17.0 & 16.1 & 0.0005 & 37 \\
26.03 .19 & $12: 35$ & 0.9 & 15.6 & 16.2 & 0.0007 & 37 \\
26.03 .19 & $17: 40$ & 0.9 & 14.7 & 16.3 & 0.0007 & 37 \\
\hline
\end{tabular}

Table 5. The dynamics of the gas situation in the $13^{\text {th }}$ southern belt entry (degassing pipeline $\varnothing 326 \mathrm{~mm}$ )

Point $3.13^{\text {th }}$ southern belt entry of block No. 10 (degassing pipeline Ø $326 \mathrm{~mm}$ )

\begin{tabular}{ccccccc}
\hline \multirow{2}{*}{ Date } & \multirow{2}{*}{ Time } & $\begin{array}{c}\mathrm{CO}_{2}, \\
\%\end{array}$ & $\begin{array}{c}\mathrm{CH}_{4}, \\
\%\end{array}$ & $\begin{array}{c}\mathrm{O}_{2}, \\
\%\end{array}$ & $\mathrm{CO}, \%$ & $\begin{array}{c}Q, \\
\mathrm{~m}^{3} / \mathrm{min}\end{array}$ \\
\hline 23.03 .19 & $12: 40$ & 1.3 & 7.55 & 17.7 & 0.0005 & 52 \\
23.03 .19 & $17: 55$ & 0.6 & 6.7 & 18.5 & 0.0002 & 52 \\
23.03 .19 & $23: 10$ & 0.7 & 6.4 & 18.3 & 0.0007 & 52 \\
24.03 .19 & $06: 10$ & 0.7 & 5.9 & 19.1 & 0.0005 & 52 \\
24.03 .19 & $11: 40$ & 0.6 & 8.2 & 18.2 & 0.0007 & 52 \\
24.03 .19 & $19: 00$ & 0.6 & 7.8 & 17.6 & 0.0006 & 52 \\
25.03 .19 & $01: 00$ & 1.0 & 7.8 & 17.5 & 0.0008 & 52 \\
25.03 .19 & $07: 10$ & 0.8 & 7.7 & 17.7 & 0.0007 & 52 \\
25.03 .19 & $12: 30$ & 1.0 & 8.4 & 17.6 & 0.0008 & 52 \\
25.03 .19 & $18: 20$ & 0.8 & 7.7 & 16.7 & 0.0007 & 52 \\
26.03 .19 & $01: 45$ & 0.6 & 6.7 & 17.7 & 0.0005 & 52 \\
26.03 .19 & $06: 35$ & 0.8 & 9.2 & 18.1 & 0.0005 & 52 \\
26.03 .19 & $12: 40$ & 0.6 & 5.1 & 19.0 & 0.0005 & 52 \\
26.03 .19 & $17: 50$ & 0.8 & 8.8 & 18.2 & 0.0008 & 52 \\
27.03 .19 & $01: 10$ & 0.5 & 8.1 & 17.8 & 0.0005 & 52 \\
\hline
\end{tabular}

Table 6. The dynamics of the gas situation in the $13^{\text {th }}$ southern belt entry (pipeline of isolated methane drainage by fan VMTSG-7M)

Point $4.13^{\text {th }}$ southern belt entry of block No. 10 (pipeline of the isolated methane drainage by fan VMTSG-7M)

\begin{tabular}{ccccccc}
\hline Date & Time & $\begin{array}{c}\mathrm{CO}_{2}, \\
\%\end{array}$ & $\begin{array}{c}\mathrm{CH}_{4}, \\
\%\end{array}$ & $\begin{array}{c}\mathrm{O}_{2}, \\
\%\end{array}$ & $\mathrm{CO}, \%$ & $\begin{array}{c}Q, \\
\mathrm{~m}^{3} / \mathrm{min}\end{array}$ \\
\hline 23.03 .19 & $12: 45$ & 0.1 & 0.6 & 20.2 & 0.0001 & 210 \\
23.03 .19 & $18: 00$ & 0.1 & 0.7 & 20.2 & 0.0001 & 210 \\
23.03 .19 & $23: 00$ & 0.1 & 0.9 & 20.2 & 0.0003 & 210 \\
24.03 .19 & $06: 15$ & 0.1 & 0.7 & 20.3 & 0.0001 & 210 \\
24.03 .19 & $11: 50$ & 0.2 & 0.8 & 20.2 & 0.0004 & 210 \\
24.03 .19 & $19: 05$ & 0.1 & 0.7 & 20.2 & 0.0003 & 210 \\
25.03 .19 & $00: 45$ & 0.1 & 0.6 & 20.0 & 0.0003 & 210 \\
25.03 .19 & $07: 20$ & 0.1 & 0.8 & 20.1 & 0.0002 & 210 \\
25.03 .19 & $12: 40$ & 0.1 & 0.5 & 20.3 & 0.0002 & 210 \\
25.03 .19 & $18: 30$ & 0.1 & 0.8 & 20.1 & 0.0004 & 210 \\
26.03 .19 & $01: 50$ & 0.1 & 0.7 & 20.2 & 0.0003 & 210 \\
26.03 .19 & $06: 45$ & 0.1 & 0.7 & 20.3 & 0.0001 & 210 \\
26.03 .19 & $12: 45$ & 0.1 & 0.7 & 20.4 & 0.0002 & 210 \\
26.03 .19 & $18: 00$ & 0.2 & 0.7 & 20.3 & 0.0003 & 210 \\
27.03 .19 & $01: 15$ & 0.1 & 1.5 & 19.9 & 0.0002 & 210 \\
\hline
\end{tabular}

Table 7. The dynamics of the gas situation in the $14^{\text {th }}$ southern belt entry (fresh jet incoming the longwall face)

Point $6.14^{\text {th }}$ southern belt entry of block No. 10 (fresh jet in-coming the longwall face)

\begin{tabular}{cccccccc}
\hline \multirow{2}{*}{ Date } & \multirow{2}{*}{ Time } & $\mathrm{CO}_{2}$, & $\begin{array}{c}\mathrm{CH}_{4}, \\
\%\end{array}$ & $\begin{array}{c}\mathrm{O}_{2}, \\
\%\end{array}$ & $\mathrm{CO}, \%$ & $\begin{array}{c}Q, \\
\mathrm{~m}^{3} / \mathrm{min}\end{array}$ & $\begin{array}{c}\mathrm{T}, \\
{ }^{\circ} \mathrm{C}\end{array}$ \\
\hline 23.03 .19 & $12: 30$ & 0.1 & 0.0 & 20.4 & 0.0000 & 3060 & 22 \\
23.03 .19 & $18: 45$ & 0.1 & 0.0 & 20.4 & 0.0000 & 3060 & 22 \\
24.03 .19 & $00: 10$ & 0.1 & 0.0 & 20.5 & 0.0000 & 3060 & 24 \\
24.03 .19 & $05: 00$ & 0.1 & 0.0 & 20.5 & 0.0000 & 3060 & 22 \\
24.03 .19 & $09: 00$ & 0.1 & 0.0 & 20.5 & 0.0002 & 3121 & 25 \\
24.03 .19 & $17: 10$ & 0.1 & 0.0 & 20.5 & 0.0002 & 3121 & 24 \\
25.03 .19 & $00: 35$ & 0.1 & 0.0 & 20.5 & 0.0002 & 3121 & 21 \\
25.03 .19 & $05: 30$ & 0.1 & 0.0 & 20.5 & 0.0002 & 3121 & 22 \\
25.03 .19 & $13: 30$ & 0.1 & 0.0 & 20.5 & 0.0002 & 3116 & 21 \\
25.03 .19 & $17: 00$ & 0.1 & 0.0 & 20.5 & 0.0002 & 3116 & 22 \\
26.03 .19 & $00: 30$ & 0.1 & 0.0 & 20.5 & 0.0002 & 3116 & 22 \\
26.03 .19 & $06: 40$ & 0.1 & 0.0 & 20.5 & 0.0000 & 3116 & 25 \\
26.03 .19 & $12: 30$ & 0.1 & 0.0 & 20.5 & 0.0001 & 3172 & 23 \\
26.03 .19 & $16: 50$ & 0.1 & 0.0 & 20.5 & 0.0000 & 3172 & 25 \\
27.03 .19 & $00: 30$ & 0.1 & 0.0 & 20.5 & 0.0002 & 3172 & 22 \\
\hline
\end{tabular}

* the indicators obtained during the repair shifts are highlighted in the Tables 3-7

The range of changes in the minimum and maximum concentrations of carbon monoxide $(\mathrm{CO})$ and methane $\left(\mathrm{CH}_{4}\right)$ is shown in Table 8 . The presented indicators did not exceed the norms specified in the Safety Regulations for Coal Mines.

Table 8. The range of changes in the concentration (\%) of $\mathrm{CO}$ and $\mathrm{CH}_{4}$ in the extraction area of the $14^{\text {th }}$ southern longwall face of block No. 10 at Mining Administration "Pokrovske"

\begin{tabular}{|c|c|c|}
\hline $\begin{array}{c}\text { The name } \\
\text { of the measuring point }\end{array}$ & $\begin{array}{c}\mathrm{CO} \\
\min \div \max \end{array}$ & $\begin{array}{c}\mathrm{CH}_{4}, \\
\min \div \max \end{array}$ \\
\hline $\begin{array}{l}13^{\text {th }} \text { southern belt entry (jet } \\
\text { outcoming from the site) }\end{array}$ & $0.0001 \div 0.0003$ & $0.5 \div 0.9$ \\
\hline Degassing pipeline $\varnothing 426 \mathrm{~mm}$ & $0.0005 \div 0.0009$ & $10.9 \div 22.0$ \\
\hline Degassing pipeline $\varnothing 326 \mathrm{~mm}$ & $0.0002 \div 0.0008$ & $5.1 \div 9.2$ \\
\hline $\begin{array}{l}\text { Pipeline of the isolated methane } \\
\text { drainage by fan VMTSG-7M }\end{array}$ & $0.0001 \div 0.0004$ & $0.5 \div 1.5$ \\
\hline $\begin{array}{l}14^{\text {th }} \text { southern belt entry (fresh } \\
\text { jet incoming the longwall face) }\end{array}$ & $0.0000 \div 0.0002$ & $0.0 \div 0.0$ \\
\hline
\end{tabular}


The maximum carbon monoxide content during stope works on the outcomig jet of the extraction area was $0.0003 \%$, which is an increase by 3.0 times and confirms the assumption about the carbon monoxide formation during the coal destruction as by mining machines, so by rock pressure.

Analyzing the results obtained, it can be stated that the air incoming the stope face of this longwall face has a background level, \%: $\mathrm{CO}=0.0000-0.0002$. After the passage of air through the stope mine working and the mined-out space, this indicator increases to the level, respectively, $\mathrm{CO}=0.0001-0.0003$, that is, it increases up to 3 times. In hard-to-reach places, namely in degassing wells and in the collapsed area of the mined-out space, where air access is limited and the gas mixture is not diluted, the minimum gas level is greater and amounted to $\mathrm{CO}=0.0005 \%$.

European standards establish that to identify sources of spontaneous heating and spontaneous ignition of coal, data on the volume of tracer gases that are generated in the mine working network are required. The emission of more than $10 \mathrm{l} / \mathrm{min}$ of $\mathrm{CO}$ in the extraction area indicates the beginning of coal spontaneous heating, and more than $251 / \mathrm{min}$ - its ignition [20]. Sensors of carbon monoxide and air velocity of continuous automatic control by UTAS and KAGI systems are distributed in different ventilation system branches, and not alongside, and this fact does not allow to accurately calculate the absolute emissions of methane $I_{\text {діл.p }}, \mathrm{m}^{3} / \mathrm{min}$ and carbon monoxide $V_{\mathrm{CO}}, 1 / \mathrm{min}$.

To be more specific about the gas-dynamic processes mechanism in mine workings of the extraction area of the $14^{\text {th }}$ southern longwall face, computer visualization of the data in Tables 3-7 has been made using the MATLAB system and Simulink extension packages [32]. The carbon monoxide flowrate $\left(V_{\mathrm{CO}}, 1 / \mathrm{min}\right)$, when conducting the stope works and during repair shifts, has been calculated. After that, the difference has been obtained between the value of $V_{\mathrm{CO}}, 1 / \mathrm{min}$ volume, which was incoming the extraction area (data in Table 7) and the one that was outcoming from the extraction area (data in Table 3-6). The calculation results made it possible to visualize the data in Figure 4.

It has been set that the carbon monoxide formation was of a peak character. The debit amplitude between peaks and troughs more often reached up to $3 \mathrm{l} / \mathrm{min}$, in the range from $1.5-4.5 \mathrm{l} / \mathrm{min}$. The peculiarity is that the peak width did not exceed several hours, and then there was a decrease to the level of $1.5-3.01 / \mathrm{min}$. It is noteworthy an increase in the $\mathrm{CO}$ debit in the interval between the fifth and eleventh samples, as well as between the thirteenth and fifteenth. This can be explained by a temporary increase in the depression applied to the stope mine working, as follows from the data on the airflow rate in it during these periods (Table 3), which contributed to the carry-over of gases from the cavities of the extraction area.

Carbon monoxide invasion to the stope mine working occurs during operations of breaking and transporting coal within the extraction area. When these activities are stopped and there is no fresh beaten material, the flow of tracer gas is reduced to the background content level. This is confirmed by the data obtained during the operation of the $11^{\text {th }}$ southern longwall face in March-April 2019 [33], in which there was observed a tendency to a peak increase in the $\mathrm{CO}$ debit during working shifts and the troughs formation during repair ones (Fig. 5).

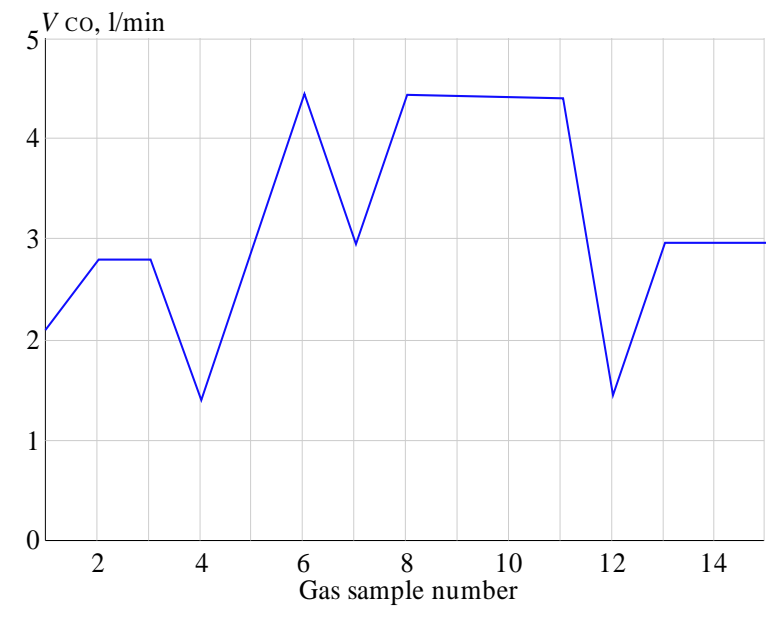

Figure 4. The dynamics of the carbon monoxide (Vco, l/min) formation in the $13^{\text {th }}$ southern belt entry of block No. 10 at Mining Administration "Pokrovske", jet outcoming from the mining site (data in Table 3)

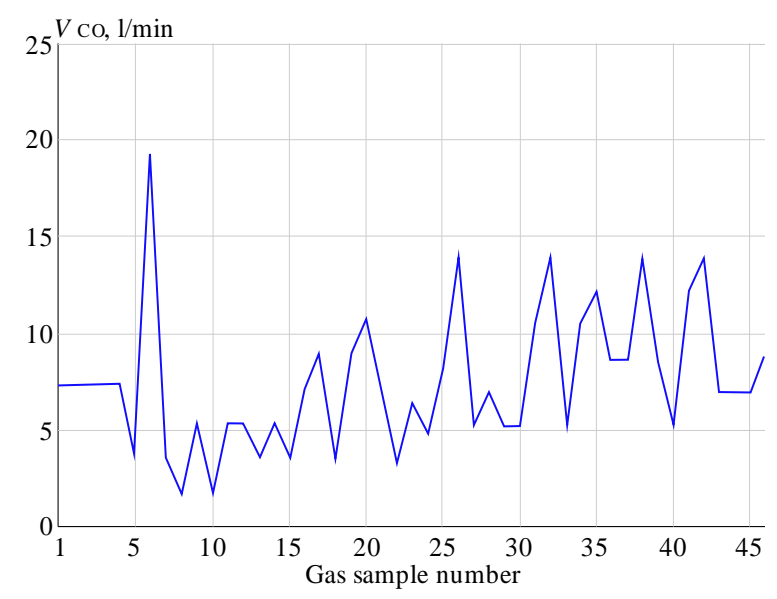

Figure 5. The dynamics of the carbon monoxide (Vco, $1 /$ min) formation in the extraction area of the of the $11^{\text {th }}$ southern longwall face at Mining Administration "Pokrovske" from 04/03/2019 to 04/14/2019 [33]

For a more accurate refinement of this pattern, it is advisable to compare the $\mathrm{CO}$ flow incoming the ventilation stream with the feed current of the combined machine and the conveying belt. Automated mine operation control systems provide such a possibility.

The results of measurements in a degassing pipeline $\varnothing 426 \mathrm{~mm}$ located in the ventilation drift of the $14^{\text {th }}$ southern longwall face confirm that the main $\mathrm{CO}$ source is located in the stope mine working (Fig. 6).

The gas dynamics in the pipeline is also of a peak character, but the carbon monoxide debit in the gas flow did not exceed $V_{\mathrm{CO}}=0.34 \mathrm{l} / \mathrm{min}$ and averaged about $0.2-0.3 \mathrm{l} / \mathrm{min}$, which is an order of magnitude less than that in the ventilation stream. Predominantly, peaks and troughs do not coincide in time with those in Figure 4, indicating different mechanisms of their formation.

When calculating the total dynamics of the tracer gas in the $14^{\text {th }}$ southern longwall face, it is taken into account that some its part comes from the $14^{\text {th }}$ southern belt entry with a fresh jet. Hence, the corrected gas dynamics is shown in Figure 7. The peaks and troughs in Figure 4 and 7 mostly coincide in time. 


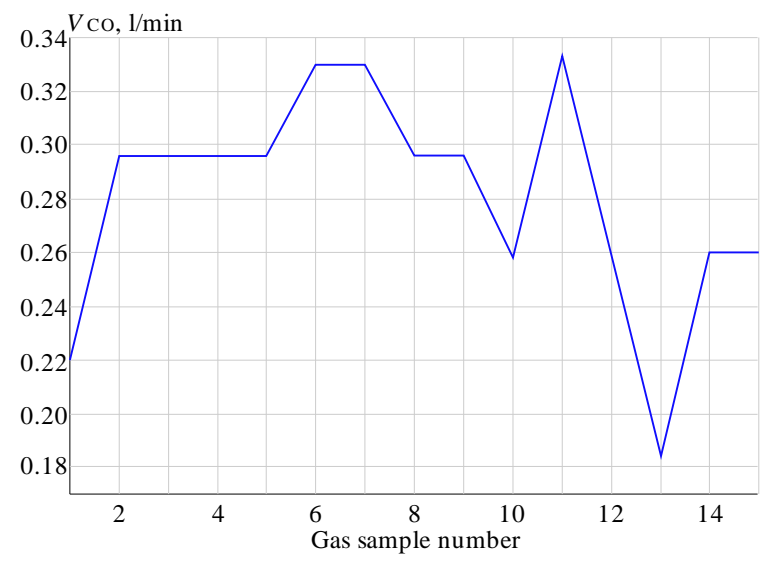

Figure 6. The dynamics of the carbon monoxide (Vco, l/min) formation in a degassing pipeline of the $14^{\text {th }}$ southern longwall face at Mining Administration "Pokrovske"

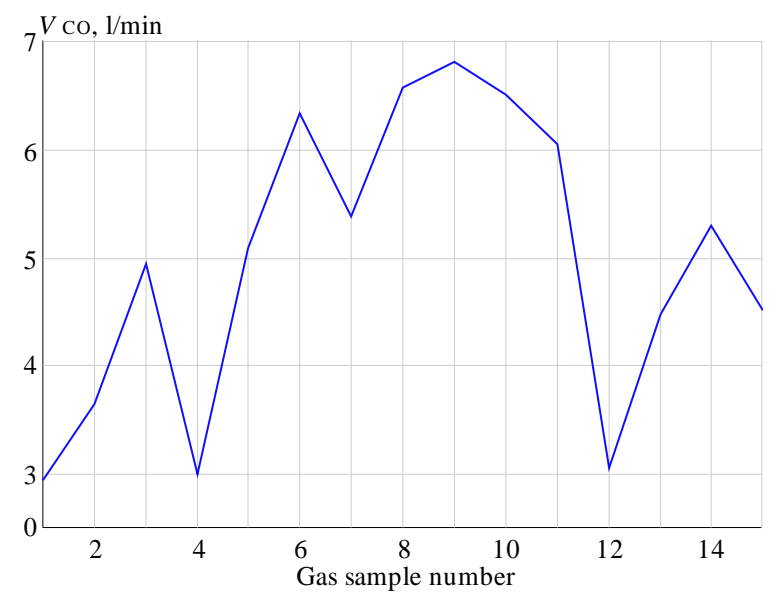

Figure 7. The corrected carbon monoxide ( $\left.V_{\mathrm{co}}, \mathrm{l} / \mathrm{min}\right)$ debit of the $14^{\text {th }}$ southern longwall face at Mining Administration "Pokrovske"

It can be hypothesized that the unstable carbon monoxide debit in a specified mine working is mainly conditioned by the mechanical coal destruction, which occurs when the seam is collapsed by the executive body of the combined machine. The absence of a stable tendency toward an increase in the $\mathrm{CO}$ content in the air flow with a simultaneous non-exceeding the debit level $V_{C O}=10 \mathrm{l} / \mathrm{min}$ indicates that the sources of spontaneous heating are not formed in the extraction area of the $14^{\text {th }}$ southern longwall face.

One of the reasons determining the danger of carbon monoxide contamination at workplaces is the insufficient level of knowledge about the mechanism of this gas formation in the extraction area. In fact, its formation occurs not only as a result of coal spontaneous heating, but also during extraction operations. To identify gas contamination of mine workings, both portable and stationary carbon monoxide measuring instruments are used. However, not all mining sites are equipped with stationary equipment for measuring $\mathrm{CO}$. This determines the problem of developing effective operational solutions to provide protection against exceeding carbon monoxide concentration standards, identifying technological and emergency gas contamination.

It can be assumed that the CO fluctuations in the air jet outcoming from the site, were affected by the airflow rate in the system, the coal breaking velocity, as well as the processes of collapsing the immediate roof and the main roof sub- sidence of the seam. The CO fluctuations in the flow of the degassing jet are conditioned by the operating mode of the vacuum-pump station, changes in the resistance of the suction part of the degassing pipelines, air jets incoming the mined-out space, collapse of the immediate roof and the main roof subsidence. Ventilation and degassing flows have an indistinct relation in time and space. They allow at a first approximation, the place of formation of coal spontaneous heating sources, but this requires their separate control by automatic means.

There is a need for appropriate modernization of systems such as UTAS, KAGI type or other types. These systems need to be improved in terms of configuration, measurement accuracy and response time, as well as signal transmission speed. Their development is also in the direction of expanding functionality, adapting to the needs of the user. One of the modern ways of complex systems improvement is to apply mathematical modelling, for example, using Matlab application software programs with the Simulink extension packages. This will allow a continuous monitoring of extraction sites from the point of view of identifying and preventing aerological threats and the danger of endogenous fires.

Unfortunately, there is a problem in that the majority of specialized companies-developers - Petrovskyi Coal Machine Building Plant (Donetsk), Makiivka Research State Institute for Mining Works Safety (Makiivka) and some others, have remained in the territory uncontrolled by Ukraine. This slows down the development and implementation in the industry of modern means for mines fire safety.

\section{Conclusions}

Endogenous fires are one of the most dangerous types of underground accidents in coal mines and they develop slowly in hard-to-reach places. They result in the largest output losses, the significant duration and complexity of emergency rescue operations. Identifying the sources of spontaneous heating and spontaneous ignition is still a challenge in all coal-mining countries. As a result of the war, in mines controlled by Ukraine, there are currently no means and methods for the operational tracking the thermodynamic processes at the mining sites of the coal mines. This has created a threat to the state energy security.

The automatic gas control (AGC) systems operating in mines are not designed to identify emergencies related to the spontaneous heating of coal in mine workings, however, there are technical possibilities for this. The sensors which are mounted in mine workings, measure with sufficient accuracy the content of such a tracer gas as carbon monoxide, the dynamics of which may indicate the emergence of spontaneous heating and spontaneous ignition sources.

It has been substantiated that improvement of the existing AGC systems by adding the sensors for measuring tracer gases and airflow rate, when incoming and outcoming from the extraction site, as well as the "artificial intelligence" to information processing units to determine the absolute and relative readings, will make possible to determine the sources of spontaneous coal heating at early stages. The tracer gases release occurs during spontaneous heating of coal, as well as during mechanical seam destruction by mining tools. However, the mechanisms of their formation are different, which makes it possible to distinguish mechanical destruction from thermal degradation by means of automatic gas protection of mines. 
At Mining Administration "Pokrovske", in the absence of spontaneous heating sources, the gas samples were selected in the $14^{\text {th }}$ southern longwall face of block No. 10 on March 23-27, 2019. The results of laboratory tests have shown an increase in carbon monoxide in mine workings from $0.0000-0.0002 \%$ in the air jet, incoming the site, to $0.0001-0.0003 \%$ in the jet, outcoming from the site. The maximal invasion of carbon monoxide to the stope mine working occurred during operations of breaking and transporting coal within the extraction area. And when these activities were stopped and there was no fresh beaten material, the flow of tracer gas was reduced to the background content level. This indicates that, in contrast to the steadily increasing during the spontaneous heating process, the tracer gas was formed periodically during the process of breaking the coal, and was an application to the background level.

\section{Acknowledgements}

The authors express their gratitude to the management of the State Militarized Rescue Service of the Ministry of Energy and Environment Protection of Ukraine, the workers of the gas analysis laboratory of No. 10 Mine-Rescue Squad for the provided opportunity to use the gas-air survey materials and the composition results of the taken air samples in the research.

\section{References}

[1] Mohalik, N.K., Khan, A.M., Kumar, A., Ray, S.K., Mishra, D., Varma, N.K., \& Sahay, N. (2019). Optimization of ventilation system for prevention of spontaneous heating/fire during extraction of thick coal seam - A CFD approach. Journal of Mines, Metals and Fuels, 67(10), 452-460.

[2] Brodny, J., \& Tutak, M. (2018). Determination of the zone with a particularly high risk of endogenous fires in the goaves of a longwall with caving. Journal of Applied Fluid Mechanics, 11(3), 545-553. https://doi.org/10.29252/jafm.11.03.27240

[3] Ciesielczuk, J., Janeczek, J., \& Cebulak, S. (2013). The cause and progress of the endogenous coal fire in the remediated landfill in the city of katowice. Przeglad Geologiczny, 61(12), 764-772.

[4] Filatov, Y.M., Igishev, V.G., Shlapakov, P.A., Shiryaev, S.N., \& Shlapakov, E.A. (2018). New regulatory framework for endogenous fires problems in coal mines. Ugol', (2), 67-70. https://doi.org/10.18796/0041-5790-2018-2-67-70

[5] Stracher, G.B., Praksh, A., \& Sokol, E.V. (2015). Coal and peat fires, A Global Perspective. Case studies - Coal fires. Amsterdam, The Netherlands: Elsevier.

[6] Trenczek, S. (2014). Charakterystyka zagrożeń naturalnych (Characteristics of natural hazards). Monitorowanie, telemetria $i$ narzędzia informatyczne $w$ górnictwie dla poprawy bezpieczeństwa pracy wybrane zagadnienia (Monitoring, telemetry and IT tools in mining to improve work safety - selected issues). Katowice, Poland: Wydawnictwo ITI EMAG.

[7] Pivnyak, G.G., \& Shashenko, O.M. (2015). Innovations and safety for coal mines in Ukraine. Naukovyi Visnyk Natsionalnoho Hirnychoho Universytetu, (6), 118-121.

[8] KD 12.01.401-96. (1997). Endohenni pozhezhi na vuhilnykh shakhtakh Donbasu. Poperedzhennia i hasinnia. Donetsk: NDIHS NVO Respirator.

[9] Bondarenko, V.I., Kharin, Ye.N., Antoshchenko, N.I., \& Gasyuk, R.L. (2013). Basic scientific positions of forecast of the dynamics of methane release when mining the gas bearing coal seams. Naukovyi Visnyk Natsionalnoho Hirnychoho Universytetu, (5), 24-30.

[10] Gamiy, Y., Liashok, Y., Kostenko, V., Zavialova, O., \& Kostenko, T. (2019). Applying European approach to predict coal self-heating in Ukrainian mines. Mining of Mineral Deposits, 13(1), 86-94. https://doi.org/10.33271/mining13.01.086

[11] Law, B.E., Ulmishek, G.F., Clayton, J.L., Kabyshev, B.P., Pashova, N.T., \& Krivosheya, V.A. (1998). Basin-centered gas evaluated in Dnieper-Donets basin, Donbas foldbelt, Ukraine. Oil and Gas Journal, 96(47), 74-78.
[12] Sotskov, V., \& Saleev, I. (2013). Investigation of the rock massif stress strain state in conditions of the drainage drift overworking. Annual Scientific-Technical Colletion - Mining of Mineral Deposits, 197-201. https://doi.org/10.1201/b16354-36

[13] Sdvizhkova, Ye.A., Babets, D.V., \& Smirnov, A.V. (2014). Support loading of assembly chamber in terms of Western Donbas plough longwall. Naukovyi Visnyk Natsionalnoho Hirnychoho Universytetu, (5). 26-32

[14] Bondarenko, V., Symanovych, G., Koval, O. (2012). The mechanism of over-coal thin-layered massif deformation of weak rocks in a longwall. Geomechanical Processes During Underground Mining Proceedings of the School of Underground Mining, 41-44. https://doi.org/10.1201/b13157-8

[15] Khalymendyk, I., \& Baryshnikov, A. (2018). The mechanism of roadway deformation in conditions of laminated rocks. Journal of Sustainable Mining, 17(2), 41-47. https://doi.org/10.1016/j.jsm.2018.03.004

[16] Lozynskyi, V.G., Dychkovskyi, R.O., Falshtynskyi, V.S., Saik, P.B., \& Malanchuk, Ye.Z. (2016). Experimental study of the influence of crossing the disjunctive geological faults on thermal regime of underground gasifier. Naukovyi Visnyk Natsionalnoho Hirnychoho Universytetu, (5). 21-29

[17] Aitkazinova, S., Soltabaeva, S., Kyrgizbaeva, G., Rysbekov, K., \& Nurpeisova, M. (2016). Methodology of assessment and prediction of critical condition of natural-technical systems. Scientific GeoConference Surveying Geology and Mining Ecology Management, 3-10. https://doi.org/10.5593/sgem2016/b22/s09.001

[18] Feng, X., \& Adamus, A. (2014). Overview of research and use of indicator gases of coal spontaneous combustion in China / Přehled Výzkumu a Využití Indikačních Plynů Samovznícení Uhlí V Č́ně. GeoScience Engineering, 60(1), 55-65. https://doi.org/10.2478/gse-2014$\underline{0006}$

[19] Zhu, H., Chang, M., \& Wang, H. (2017). Study on primal CO gas generation and emission of coal seam. International Journal of Mining Science and Technology, 27(6), 973-979. https://doi.org/10.1016/j.ijmst.2017.06.002

[20] Trenchek, S. (2017). Assessment of methane and spontaneous fire hazards level in the areas ventilated by refreshment of returned air in light of the applicable regulations. Katowice, (10), 21-28.

[21] Krzystanek, Z., Mróz, J., \& Trenczek, S. (2016). Integrated system for monitoring and analysis of methane hazards in the longwall area. Mining - Informatics, Automation and Electrical Engineering, 1(525), 21-32.

[22] Zubicek, V. (2015). Selected methods for determining susceptibility to spontaneous combustion of coal mass in The Czech Republic and foreign countries. Kosice, Slovakia.

[23] Šofranko, M. (2014). Methodology of risk analysis of endogenous fire in coal mines. Advanced Materials Research, (962-965), 1153-1157. https://doi.org/10.4028/www.scientific.net/amr.962-965.1153

[24] Cierpisz, S., Miśkiewicz, K., \& Wojaczek, A. (2007). Systemy gazometryczne w górnictwie (Gas measurement systems in mining). Gliwice, Poland: Wydawnictwo Politechniki Śląskiej.

[25] Gillies, A.D.S, Wu, H.W., Tuffs, N., \& Sartor, T. (2004). Development of a real time airflow monitoring and control system. Proceedings of the $10^{\text {th }}$ US/North American Mine Ventilation Symposium, 1-8.

[26] Trenczek, S., \& Wojtas, P. (2014). Rozwój monitorowania zagrożeń naturalnych w okresie ostatniego 20-lecia (Development in natural hazards monitoring during the last 20 years). Bezpieczeństwo Pracy $i$ Ochrona Środowiska w Górnictwie, (9), 3-10.

[27] Wasilewski, S. (2010). Automatic gas measurement. Innowacje dla gospodarki (Innovations for the economy). Katowice, Poland: Wydawnictwo ITI EMAG.

[28] Dixon, W.D. (1992). A statistical analysis of monitored data for methane prediction. Extended Abstract of PhD Dissertation. Nottingham, United Kingdom: University of Nottingham.

[29] Noack, K. (1998). Control of gas emissions in underground coal mines. International Journal of Coal Geology, 35(1-4), 57-82. https://doi.org/10.1016/s0166-5162(97)00008-6

[30] Sikora, M., Krzystanek, Z., Bojko, B., \& Śpiechowicz, K. (2011). Application of a hybrid method of machine learning for description and on-line estimation of methane hazard in mine workings. Journal of Mining Science, 47(4), 493-505. https://doi.org/10.1134/s1062739147040125

[31] Kerivnytstvo $z$ proektuvannia ventyliatsii vuhilnykh shakht. (1994). Kyiv, Ukraina: Osnova.

[32] Diakonov, V.P. (2002). Matlab 6/6.1/6.5 + Simulink 4/5. Osnovy zastosuvannia. Povne kerivnytstvo korystuvacha. Kyiv, Ukraina: Solon-Press.

[33] Hamii, Yu. (2019). Obhruntuvannia kontroliu hazovydilennia oksydu vuhletsiu na prykladi 11 pivdennoi lavy bloka \#10. In Forum Hirnykiv (pp. 273-283). Dnipro, Ukraina: Zhurfond. 


\section{Виявлення джерел самонагрівання вугілля у виробках за допомогою автоматичних систем аерогазового контролю}

\section{Ю. Гамій, В. Костенко, О. Зав’ялова, Т. Костенко, Д. Журбинський}

Мета. Дослідження аерогазової обстановки на видобувній дільниці вугільної шахти для обгрунтування можливості розширення функцій сучасних систем автоматичного газового контролю (АГК) при їх використанні у виявленні процесів самонагрівання, самозаймання вугілля та загазованості.

Методика. В роботі виконано дослідження динаміки відбору 15 газових проб повітрярозподілення зі встановлених місць, із використанням системи MATLAB і пакетів розширення Simulink. Відбір газових проб здійснено в 14-ї південній лаві блоку №10 шахтоуправління “Покровське” протягом 23.03.2019-27.03.2019, де 15.03.2019 року трапилась аварійна ситуація, пов'язана із загазованістю.

Результати. Виконано обробку дослідних даних виділення оксиду вуглецю у виробках виїмкової дільниці, лаві, технологічних трубопроводах повітрярозподілення. Встановлено збільшення оксиду вуглецю у виробках від 0.0000-0.0002\% у струмені повітря, що поступало до дільниці, до 0.0001-0.0003\% у струмені, що виходив з дільниці, при цьому пікоподібна інвазія оксиду вуглецю до очисної виробки відбувалась при операціях відбійки і транспортування вугілля в межах виїмкової дільниці, а при зупинці цих видів робіт і відсутності свіжого відбитого матеріалу - скорочувалась до фонового. Доведено, що удосконалення існуючих систем АГК додаванням датчиків для вимірювання індикаторних газів і витрат повітря, а також додавання “штучного інтелекту” блокам обробки інформації для визначення абсолютних та відносних показань дозволять виявляти на ранніх стадіях джерела самонагрівання вугілля.

Наукова новизна. Для умов пласта $d 4$ виявлено характер і особливості виділення оксиду вуглецю, впливу провітрювання, при виїмкових роботах на видобувній дільниці, в той час як попередні відомі дослідження присвячені виділенню оксиду вуглецю 3 пластів $k_{5}, l_{1}, m_{4}^{2}$ при зміні гранулометричного складу.

Практична значимість. Постійний моніторинг аерологічних загроз дозволить вжити відповідні заходи для обмеження наслідків вентиляційно-газової небезпеки, небезпеки ендогенних пожеж.

Ключові слова: системи АГК, самонагрівання та самозаймання вугілля, виїмкова дільниия, ендогенна пожежа

\section{Выявление источников самонагревания угля в выработках с помощью автоматических систем аэрогазового контроля}

\section{Ю. Гамий, В. Костенко, Е. Завьялова, Т. Костенко, Д. Журбинский}

Цель. Исследование аэрогазовой обстановки на добывающем участке угольной шахты для обоснования возможности расширения функций современных систем автоматического газового контроля (АГК) при их использовании в выявлении процессов самонагревания, самовозгорания угля и загазованности.

Методика. В работе выполнено исследование динамики отбора 15 газовых проб воздухораспределения с установленных мест, с использованием системы MATLAB и пакетов расширения Simulink. Отбор газовых проб осуществлен в 14-й южной лаве блока №10 шахтоуправления "Покровское” в течение 23.03.2019-27.03.2019, где 15.03.2019 года произошла аварийная ситуация, связанная с загазованностью.

Результаты. Выполнено обработку опытных данных выделения оксида углерода в выработках выемочного участка, лаве, технологических трубопроводах воздухораспределения. Установлено увеличение оксида углерода в выработках от 0.0000-0.0002\% в поступающей струе воздуха, на участок до 0.0001-0.0003\% в исходящей струе, при этом пикообразная инвазия оксида углерода в очистной выработке происходила при операциях отбойки и транспортировки угля в пределах выемочного участка, а при остановке этих видов деятельности и отсутствия свежего отбитого материала - сокращалась до фонового. Доказано, что усовершенствование существующих систем АГК добавлением датчиков для измерения индикаторных газов и расхода воздуха, а также добавление “искусственного интеллекта" блокам обработки информации для определения абсолютных и относительных показаний позволят выявлять на ранних стадиях источники самонагревания угля.

Научная новизна. Для условий пласта $d_{4}$ выявлен характер и особенности выделения оксида углерода, влияния проветривания, при выемочных работах на добывающей участок, в то время как предыдущие известные исследования посвящены выделению оксида углерода из пластов $k_{5}, l_{1}, m_{4}^{2}$ при изменении гранулометрического состава.

Практическая значимость. Постоянный мониторинг аэрологических угроз позволит принять соответствующие меры для ограничения последствий вентиляционно-газовой опасности, опасности эндогенных пожаров.

Ключевые слова: системы АГК, самонагревание и самовозгорание угля, выемочный участок, эндогенный пожар

\section{Article info}

Received: 22 August 2019

Accepted: 28 February 2020

Available online: 5 March 2020 